\title{
Does Low-Protein Diet Improve Broiler Performance under Heat Stress Conditions?
}

\section{Author(s)}

Furlan RL

Faria Filho DE de

Rosa PS

Macari M

Unesp - Universidade Estadual Paulista

Faculdade de Ciências Agrárias e Veterinárias

Campus de Jaboticabal

\section{Mail Address}

Renato Luis Furlan

Via de acesso Paulo Donato Castellane, s/n

14.884-900 - Jaboticabal, SP

E-mail: rlfurlan@fcav.unesp.br

\section{Keywords}

Broiler chickens, crude protein, heat stress, heat increment, heat production.

\section{ABSTRACT}

Nutrition for broilers under high temperatures is extremely important for brazilian broiler chicken industry because the amounts of consumed nutrients and environmental temperature have great effects on bird performance and carcass quality. Among diet nutrients, protein has the highest heat increment; thus, during many years, diets with low protein level were recommended in order to reduce heat production in broiler chickens under heat stress. However, reports have shown that lowprotein diets have negative effects on broiler performance when environmental temperature is high, because during heat stress, low food intake associated to a low diet protein induce amino acid deficiencies. Other studies have shown that broilers fed low-protein diets increase their energy requirement for maintenance with higher heat production. Thus, with the growth of broiler industry in tropical areas more challenges need to be faced by the farmers. So, both the ambient and nutritional conditions ought to be well managed to avoid negative effects on poultry production once they can affect the metabolism (body heat production under low temperature and body heat dissipation under high temperature) with consequence on poultry performance (meat and eggs).

\section{INTRODUCTION}

Broiler chickens are homoeothermic animals, which means that they maintain their central body temperature within a slight range irrespective of ambient temperature. So, birds have a thermoneutral zone that should be described as being a range in the environmental temperature in which energy needs for thermoregulation is minimum and the net energy for production is maximum (Furlan \& Macari, 2002). Heat stress is one of the most important factors responsible by losses in animal production traits. Ain Baziz et al. (1996) observed that in heat-stressed birds body weight gain reduced more than food intake, since part of metabolizable energy intake was used for heat dissipation, impairing feed conversion.

The improvement of rearing conditions during heat stress can be done by interfering in the ambient (fans, fogging, and bird density), building (ceiling height, roof type, and localization), breeding (lines more resistant to heat) and nutritional practices (protein, energy, electrolytes). Among nutritional practices, reduction of diet protein level due to its greater heat increment compared to carbohydrate and fat (Musharaf \& Latshaw, 1999) have been recommended during many years, aiming to reduce the amount of heat to be dissipated by the broiler chickens under heat stress (Waldroup, 1982). Nevertheless, recent findings have demonstrated that diets with low concentrations of crude protein 
Furlan RL, Faria Filho DE de, Rosa PS, Macari M
Does Low-Protein Diet Improve Broiler Performance under Heat Stress Conditions? worsen performance of broilers reared under heat stress (Alleman \& Leclerq, 1997; Faria Filho, 2003).

This review discuss the effects of protein levels in the diets, formulated using the ideal protein concept, on broiler chickens performance when raised under heat stress conditions.

\section{LOW-PROTEIN DIETS UNDER HEAT STRESS}

Ideal protein should be understood as being that that has all amino acids in the exact amount and proportion for attending the maintenance and the highest protein deposition requirements. According the ideal protein concept, all amino acids are equally limiting to animal growth; thus, reduction of any amino acid, independent of the level, will cause its own deficiency and protein will become non-ideal. The first ideal protein profile for broiler chickens was published by Baker \& Han (1994). The recommended profile was based on many trials carried out by researchers from University of Illinois(Klain et al., 1960; Dean \& Scott, 1965; Huston \& Scott, 1968; Sasse \& Baker, 1973; Baker et al., 1979), where purified diets (synthetic amino acids) were tested aiming to establish a standard amino acid profile for attending broiler chickens requirements at initial phase.

Despite many studies had been done for evaluating the effect of diet protein on broiler performance, very few studies have been done comparing the different amino acid profiles for broiler chickens growth and body composition. More recently, investigations evaluating diet protein levels at initial phase showed that protein reduction affect chick performance (Araújo, 2001; Costa et al., 2001; Hussein et al., 2001; Bregendahl et al., 2002; Faria Filho, 2003). During the growing phase, the findings are more contradictory. Costa et al. (2001) and Sterling et al. (2002) supplemented low-protein diets with methionine, lysine and threonine and found a reduction in the performance when compared to control diet. On the other hand, Araújo (2001), using these same amino acids (methionine, lysine and threonine), reported that is possible to use diets containing $17 \%$ of protein without affecting broiler chicken performance. Ferguson et al. (1998b) and Sabino (2001) using these same amino acids, and including tryptophan, reported a reduction in the performance of the broiler chickens when fed with lowprotein diets.

Kerr \& Kidd (1999a) using growing diets with protein ranging from 19 to $13 \%$, reported that it should be possible to reduce two percent of diet protein content without affecting weight gain and feed conversion when methionine and lysine were added. When glutamic acid and essential amino acids were added (following ideal profile recommended by Baker \& Han (1994) data of weight gain was worst than those obtained when only lysine and methionine were used. The findings also revealed that the reduction of four percent in the protein diet did not affect feed conversion. In other study, Kerr \& Kidd (1999b) verified that feeding birds with a diet of $18.2 \%$ of protein, threonine-supplemented or not, did not affect weight gain and feed conversion.

\section{Protein intake vs environmental temperature}

It is well known that environment influence animal performance, so the acute or chronic effects of environmental variables need to be considered; on the other hand, and authors have been reported that protein has higher caloric increment than carbohydrate and fat (Musharaf \& Latshaw, 1999). Heat increment is represented by energy released during digestion, absorption and nutrient metabolism and other metabolic mechanisms related to physiological/ metabolic events (Pond et al., 1995). On the other hand, the term "heat production" is related to heat increment plus energy lost with maintenance (Church \& Pond, 1977), which is required for thermal modulation (body temperature maintenance), normal activity (walking, eating, drinking) and basal metabolism (energy spent for vital process during fasting, resting at thermoneutral temperature). So, considering that protein has high caloric increment, reduction of diet crude protein level has being recommended for broiler chickens under heat stress aiming to decrease the amount of heat produced by animals and to reduce their harmful effects on bird performance.

Studies have demonstrated that low-protein diets increase heat production. Nieto et al. (1997) feeding broilers with low-protein diet (6.6 vs $20.0 \%$ ) from $10^{\text {th }}$ to $24^{\text {th }}$ day of age reported an increase in the requirement of metabolizable energy for maintenance

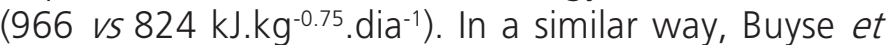
al. (1992) found that low-protein diets (15 vs 20\%) increased heat production $(1,254$ vs $1,059 \mathrm{~kJ} . \mathrm{kg}$ 0.75 . day ${ }^{-1}$, respectively) by 28 day-old broiler chickens. These results were associated to the increase of plasma level of thyroid hormone triiodothyronine $\left(T_{3}\right)$ in broiler chickens fed low-protein diets (Buyse et al., 1992). It is well known heat stress decreases feed intake and causes nutrient deficiency. Deficiency of arginine, 
Furlan RL, Faria Filho DE de, Rosa PS, Macari M lysine, isoleucine, methionine (Carew et al., 1997) and tryptophan (Carew et al., 1983) increase plasma concentration of $\mathrm{T}_{3}$ in broiler chickens and, consequently, increased heat production of broiler fed low-protein diets.

Nevertheless, Alleman \& Leclerq (1997) observed that the low performance of broiler chickens raised under heat stress $\left(32^{\circ} \mathrm{C}\right)$ from 21 to 42 days of age, was impaired when protein level was reduced from 20 to $16 \%$ in the diets supplemented with methionine, lysine, threonine, arginine and valine. Recently, Faria Filho (2003) evaluating diets with low protein content (20\%, $18.5 \%$ and $17 \%)$, formulated according to ideal protein concept for broiler chickens from 21 to 42 days of age and raised at 20,25 or $33^{\circ} \mathrm{C}$, observed a reduction of weight gain and feed conversion in birds at $33^{\circ} \mathrm{C}$, but, at 20 or $25^{\circ} \mathrm{C}$ there were no performance changes (Figure 1). These findings did not support the hypothesis that crude protein might be reduced in diets for heat-stressed broilers due to its high caloric increment.
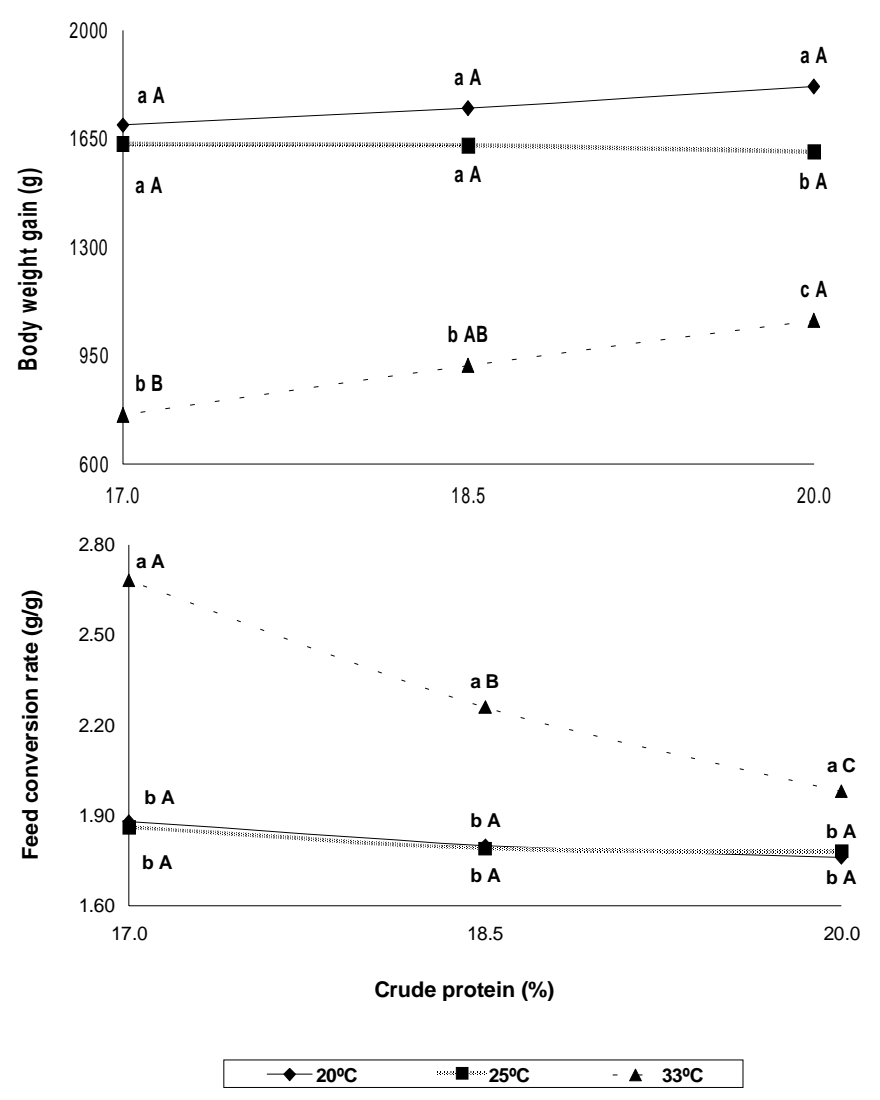

Figure 1 - Effects of crude protein in each temperature (capital letters in horizontal) and ambient temperature within each crude protein level (small letters in vertical). Means followed by different letters are statistically different by Tukey test $(p<0.05)$. Faria Filho (2003).
Does Low-Protein Diet Improve Broiler Performance under Heat Stress Conditions?

\section{Protein intake vs feed intake}

It is well known that birds reduce feed intake under heat stress conditions. According to Ain Baziz et al. (1996), broiler chickens reduce feed intake around $3.6 \%$ for every increase $\left(1^{\circ} \mathrm{C}\right)$ in environmental temperature from 22 to $32^{\circ} \mathrm{C}$. This reduction aims to avoid increasing of endogenous heat production since heat production is high when feed intake increase (Koh \& Macleod, 1999a,b; Longo, 2000). By the way, considering the low feed intake of heat-stressed birds associated to diets with low-protein content there is a deficiency of amino acids intake.

Some works have demonstrated that the reduction in the crude protein levels in the diet does not affect feed intake of broiler chickens (Blair et al., 1999; Sabino, 2001). Modulation of feed intake is not a consequence only of crude protein amount, but also of protein quality, meaning concentration and balance of amino acids. Faria Filho (2003) verified that lowprotein diets, formulated according to ideal protein concept, did not increase feed intake. So, the excess of essential non-limitating amino acids, usual in commercial diets, may help to avoid these nutrient deficiencies during heat stress conditions.

Reports of Sakomura (1998) revealed that there is no increase in bird metabolic requirements of amino acids at high environmental temperature, but amino acid requirements indicates how amino acids percentage in the diet should be changed according to the temperature.

\section{Protein intake vs water intake}

Water intake during heat stress is a limiting factor for survival and growth, since water has a fundamental role in heat exchange systems for temperature regulation (Furlan \& Macari, 2002) and the maintenance of hydric balance in birds. So, special management is necessary during heat stress especially that associated water (amount and quality), since the increase in water consumption reduces the increase in body temperature. Macari et al.(1994) suggested that, during heat stress, water temperature might be maintained around $20^{\circ} \mathrm{C}$. Teeter (1994) found that heat-stressed broilers drinking (30 mL. $\mathrm{Kg}^{-1}$ of live weight) water heated at $41^{\circ} \mathrm{C}$ did not change their body temperature, but when the water was offered at $12.7^{\circ} \mathrm{C}$ there was a reduction of $1^{\circ} \mathrm{C}$ in body temperature.

Another important point related to water intake is the nutritional composition of ration. Marks \& Pesti (1984) verified that broiler fed diets with $17 \%$ protein drunk significantly less water than those fed diets with 
Furlan RL, Faria Filho DE de, Rosa PS, Macari M
Does Low-Protein Diet Improve Broiler Performance under Heat Stress Conditions? high protein (26\%). Also, Alleman \& Leclercq (1997) observed that in broiler fed diets with low crude protein content $(16 \%)$ reduced water intake, independent of raising ambient temperature $\left(22\right.$ or $32^{\circ} \mathrm{C}$ ) (Figure 2 ). It is interesting to emphasize that, as expected, birds raised at $22^{\circ} \mathrm{C}$ showed increase in water intake with the age, but birds at $32^{\circ} \mathrm{C}$ had a constant water intake from $25^{\text {th }}$ to $40^{\text {th }}$ day of age. However, independent of environmental temperature, low-protein diets promoted decrease in water intake, which is undesirable in situation heat stress. These results may be related to the lower potassium content of diets with low protein level, since in this situation rations are balanced with reduced inclusion of soybean meal, an ingredient rich in this mineral.

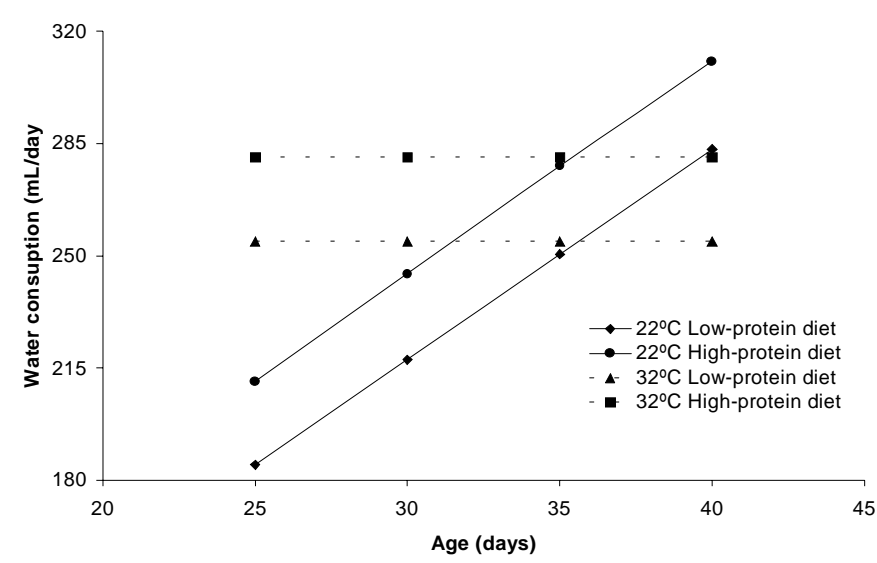

Figure 2 - Water intake by broiler chickens raised at 22 or $32^{\circ} \mathrm{C}$ and fed with low or high crude protein levels (20 vs 16\%). Alleman \& Leclerq (1997)

Trials have shown that additives, as sodium bicarbonate and potassium chloride might increase water intake. Branton et al. (1986) reported that the addition of $0.63 \%$ of bicarbonate $(6.25 \mathrm{~g}$ per liter) in drinking water of broiler under severe heat stress increased water intake in $20 \%$, and also reduced mortality. Smith \& Teeter (1987) observed better water intake, growing rate and feed conversion when $0.36 \%$ of $\mathrm{KCl}$ was added in drinking water.

It is important to consider that broiler under heat stress should have more potassium requirement due to the development of respiratory alkalosis resulted of acid-base unbalance and characterized by increase of blood $\mathrm{pH}$. Due to high respiratory frequency, partial pressure of $\mathrm{CO}_{2}$ decreases inducing concentration falls of carbonic acid and, consequently, of hydrogen ions $\left(\mathrm{H}^{+}\right)$in the blood. At this time, there is exchange of $\mathrm{H}^{+}$ by $\mathrm{K}^{+}$in renal tube for maintaining $\mathrm{H}^{+}$level. This passage of $\mathrm{K}^{+}$from outer to inner of cell causes potassium secretion to renal tube lumen. As a consequence, kidneys decrease competition between $\mathrm{H}^{+}$and $\mathrm{K}^{+}$for urine and the losses of $\mathrm{K}^{+}$increases concomitantly with its requirement by heat-stressed broilers (Borges et al., 2003). This increase in potassium requirement associated to the reduced level of this ion in low-protein diets should be consider as a threatening factor for performance of heat-stressed broilers fed diets with low-protein content.

\section{Amino acid digestibility}

There are few reports showing the effect of environmental temperature on the amino acid digestibility. In heat stress conditions, there is a decrease in amino acid digestibility, but this effect depends on bird sex, being more evident in females (Wallis \& Banalve, 1984). Brake et al. (1998), observed that broiler chickens under heat stress during the growing phase had reduced rate of arginine intestinal absorption in vitro, which led the authors to suggest the ideal arginine:lysine ration should be higher for broilers in this environmental situation.

\section{Protein intake vs carcass composition}

Besides nutritional management (amount), ration composition (quality) is other important factor affecting carcass composition. Among the different nutritional components, proteins (amino acids) are fundamentals, because they are related with synthesis of structural tissues. For example, in growing animals amino acids deposition in the skeletal muscle represent $65 \%$ of whole daily protein intake (Macari et al., 1994). However, amino acid deposition is pre-established by bird, according genetic information, in other words, there is a limit for daily deposition independent of protein intake. But daily deposition variations may be dependent on the kind of diet nutrient.

Also, it is necessary to consider that bird requirements are based on amino acids and not on crude protein (CP). Leeson \& Summers (1997) found reduction in the amount of fat deposition with the increase of diet protein, but within a range from 20 to $36 \%$ of CP there was only a small change in carcass protein content. So, for reaching maximum amino acid deposition with minimum fat deposition, the bird amino acid daily requirements need to be attended. In this way, Sklan \& Plavinik (2002) verified that birds fed diets with low protein content had their performance limited by essential amino acid deficiency. Araújo (2001) 
Furlan RL, Faria Filho DE de, Rosa PS, Macari M Heat Stress Conditions? reported a lower carcass yield in broiler fed diets with low crude protein content from 21 to 42 days of age.

Faria Filho (2003) reported that low-protein diets increased abdominal fat deposition. Aletor et al. (2000) found in broilers fed diets with crude protein ranging from 21.0 to $15.3 \%$, even when it was supplemented with non-essential amino acids (alanine, aspartic and glutamic acids) for reaching the same protein level of control diet $(22.5 \%)$, higher body fat deposition than those broilers fed control diet.

The effect of rearing temperature and diet protein level on broiler chicken chemical composition of carcass cuts is not reported in the literature. Recently, Faria Filho (2004, unpublished data) verified an increase in the ether extract and a reduction in the protein content of breast, drumstick + thigh and wings from broiler fed low-protein diets, with these effects being more strongly observed when the birds were raised under heat stress (Tables 2,3 and 4). It was also observed an increase in dry matter of drumstick + thigh and wings when the broilers were fed with diets containing lowprotein diet and reared at high ambient temperature.

\section{High-protein diets under heat stress}

Many trials were carried out for evaluating the performance of broilers chickens reared under heat stress conditions and fed high-protein diets. Temim et al. (1999) reported that feeding broiler chickens with high protein diet (25 vs 20\%) at high ambient temperature $\left(32^{\circ} \mathrm{C}\right)$ during growing period improved weight gain (Table 1). Temim et al. (2000a), testing diets with crude protein content ranging from 10 to $33 \%$, also, found an improvement in birds performance when using diets of 28 and $33 \%$ of crude protein, even when the birds were raised under heat stress.

Table 1 - Feed intake, weight gain and feed conversion of broiler chickens under thermoneutral temperature $\left(22^{\circ} \mathrm{C}\right)$ or heat stress $\left(32^{\circ} \mathrm{C}\right)$ fed diets with low or high crude protein (CP) contents $(20$ vs $25 \%$ ).

\begin{tabular}{|c|c|c|c|c|}
\hline \multirow{2}{*}{ Variables } & \multicolumn{2}{|c|}{ Thermo neutral } & \multicolumn{2}{|c|}{ Heat stress } \\
\hline & $20 \% \mathrm{CP}^{1}$ & $25 \%$ CP & $20 \%$ CP & $25 \% \mathrm{CP}$ \\
\hline Feed intake (g.day $\left.{ }^{-1}\right)$ & $162 \mathrm{a}$ & $157 a$ & $115 b$ & $122 \mathrm{~b}$ \\
\hline Weight gain (g. day $\left.{ }^{-1}\right)$ & $87.2 a$ & $89.7 a$ & $47.1 \mathrm{c}$ & $54.3 \mathrm{~b}$ \\
\hline Feed conversion & $1.86 \mathrm{c}$ & $1.76 \mathrm{~d}$ & $2.52 a$ & $2.35 \mathrm{~b}$ \\
\hline
\end{tabular}

Geraert et al. (1993) observed that diets with high protein content ( 23 vs 19\%) were able to reduced heat production in broilers under heat stress $\left(32^{\circ} \mathrm{C}\right)$ between $3^{\text {rd }}$ and $9^{\text {th }}$ week of age. Zarate et al. (2003) evaluated a commercial diet, with or without essential amino acid supplementation (10\% over commercial levels), in broiler chicken raised during the summer and concluded that amino acid supplementation had a minimum effect on heat production, with more energy utilization for fat deposition than to protein synthesis.

Temim et al. (2000b) evaluated protein turnover in Pectoralis major (breast muscle), Sartorius and Gastrocnemius (leg muscles) of broiler raised at 22 or $32^{\circ} \mathrm{C}$ and fed diets with 20 or $25 \%$ of crude protein. These authors found that high-protein diet did not change muscle protein turnover. Considering that heat production is positively correlated with body protein synthesis instead of protein intake, and there is no evidence indicating an increase of heat production due to amino acid excess (Macleod, 1997), we should speculate that utilization of high-protein diets for broiler chickens reared under heat stress is not able to change heat production in the birds. Beside, at high temperature, diets with high protein might help muscle protein synthesis due to proteolysis reduction (Temim et al., 2000b). However, high-protein diets increase nitrogen excretion (Aletor et al., 2000), which has a negative environmental impact. Thus, basically three items need to be considered for defining the better diet protein level for broiler chickens: 1) productivity; 2) final product quality (low protein diets increase fat deposition) and, 3) environmental impact (nitrogen excretion).

\section{CONCLUSIONS}

1. Low-protein diets increase maintenance energy requirement and decrease broiler chicken performance at high ambient temperature.

2. Carcass protein and fat deposition are affected by the level of protein in the diet and, also, by environmental rearing temperature.

\section{REFERENCES}

Ain Baziz HA, Geraert PA, Padilha JCF, Guillaumin S. Chronic heat exposure enhances fat deposition and modifies muscle and fat partition in broiler carcasses. Poultry Science 1996; 75:505-513.

Aletor VA, Hamid II, Nieb E, Pfeffer E. Low-protein amino acidsupplemented diets in broiler chickens: effects on performance, 
Furlan RL, Faria Filho DE de, Rosa PS, Macari M

Table 2 - Effect of environmental temperature and diet protein level on chemical composition (\% dry matter) of breast at 42 day-old broilers.

\begin{tabular}{|c|c|c|c|c|c|}
\hline \multirow[t]{2}{*}{ Variables } & \multirow{2}{*}{$\begin{array}{c}\text { Crude } \\
\text { Protein (\%) }\end{array}$} & \multicolumn{4}{|c|}{ Environmental Temperature $\left({ }^{\circ} \mathrm{C}\right)$} \\
\hline & & Hot & Cold & Thermo neutral & Mean \\
\hline \multirow{5}{*}{ Dry matter (\%) } & 20.0 (control) & $28.9 \mathrm{~b}$ & 29.3 & 29.1 & 28.4 \\
\hline & 18.5 & $29.6 a b$ & 29.9 & 28.8 & 30.0 \\
\hline & 17.0 & 30.0 a & 29.8 & 30.2 & 30.1 \\
\hline & Mean & & 29.7 & 29.4 & 29.5 \\
\hline & $\operatorname{VC}(\%)=2.51$ & & & & \\
\hline \multirow{5}{*}{ Crude Protein (\%) ${ }^{1}$} & 20.0 (control) & 73.4 & 73.5 aA & $71.2 \mathrm{aB}$ & 75.4 aA \\
\hline & 18.5 & 71.5 & $72.6 \mathrm{abA}$ & $71.5 \mathrm{aA}$ & $70.5 \mathrm{bA}$ \\
\hline & 17.0 & 70.1 & $71.6 \mathrm{bA}$ & $67.6 \mathrm{bB}$ & $71.0 \mathrm{bA}$ \\
\hline & Mean & & 72.6 & 70.1 & 72.3 \\
\hline & $\operatorname{VC}(\%)=1.30$ & & & & \\
\hline \multirow{5}{*}{ Ether extract $(\%)^{1}$} & 20.0 (control) & 20.2 & $20.1 \mathrm{bB}$ & $22.2 \mathrm{bA}$ & $18.3 \mathrm{bC}$ \\
\hline & 18.5 & 22.2 & $21.0 \mathrm{abA}$ & $22.0 \mathrm{bA}$ & 23.6 aA \\
\hline & 17.0 & 23.9 & $22.3 \mathrm{aB}$ & $26.2 \mathrm{aA}$ & $23.3 \mathrm{aB}$ \\
\hline & Mean & & 21.1 & 23.5 & 21.7 \\
\hline & $V C(\%)=3.51$ & & & & \\
\hline \multirow{5}{*}{ Mineral (\%) } & 20.0 (control) & $6.4 \mathrm{a}$ & 6.4 & 6.5 & 6.3 \\
\hline & 18.5 & $6.3 \mathrm{ab}$ & 6.3 & 6.6 & 5.9 \\
\hline & 17.0 & $6.0 \mathrm{~b}$ & 6.1 & 6.3 & 5.7 \\
\hline & Mean & & $6.3 \mathrm{~A}$ & $6.5 \mathrm{~A}$ & $6.0 \mathrm{~B}$ \\
\hline & $\operatorname{VC}(\%)=3.95$ & & & & \\
\hline
\end{tabular}

1 - Significant interaction among factors $(p<0.05)$. For each independent variable, means followed by different capital letters within line or small letter within column are statistical different by Tukey test $(p<0.05)$

Table 3 - Effect of environmental temperature and diet protein level on chemical composition (\% dry matter) of drumstick + thigh at 42 day-old broilers.

\begin{tabular}{|c|c|c|c|c|c|}
\hline \multirow{2}{*}{ Variables } & \multirow{2}{*}{$\begin{array}{c}\text { Crude } \\
\text { Protein (\%) }\end{array}$} & \multicolumn{4}{|c|}{ Environmental Temperature $\left({ }^{\circ} \mathrm{C}\right)$} \\
\hline & & Hot & Cold & Thermo neutral & Mean \\
\hline \multirow{5}{*}{ Dry matter (\%) } & 20.0 (control) & $32.4 \mathrm{~b}$ & 33.0 & 33.1 & 31.0 \\
\hline & 18.5 & $32.9 \mathrm{ab}$ & 33.3 & 33.2 & 32.1 \\
\hline & 17.0 & $33.5 \mathrm{a}$ & 33.4 & 34.2 & 32.9 \\
\hline & Mean & & $33.2 \mathrm{~A}$ & $33.5 \mathrm{~A}$ & $32.0 \mathrm{~B}$ \\
\hline & $\operatorname{VC}(\%)=1.36$ & & & & \\
\hline \multirow{5}{*}{ Crude Protein (\%) } & 20.0 (control) & $53.3 \mathrm{a}$ & 55.8 & 48.1 & 56.1 \\
\hline & 18.5 & $49.7 b$ & 51.0 & 46.7 & 51.4 \\
\hline & 17.0 & $46.5 \mathrm{C}$ & 47.7 & 43.8 & 48.1 \\
\hline & Mean & & $51.5 \mathrm{~A}$ & $46.2 \mathrm{~B}$ & $51.9 \mathrm{~A}$ \\
\hline & $\operatorname{VC}(\%)=2.92$ & & & & \\
\hline \multirow{5}{*}{ Ether extract ${ }^{1}(\%)$} & 20.0 (control) & 36.7 & $36.7 \mathrm{CAB}$ & $37.8 \mathrm{cA}$ & $35.6 \mathrm{bB}$ \\
\hline & 18.5 & 38.4 & $38.2 \mathrm{bB}$ & $40.5 \mathrm{bA}$ & $36.4 \mathrm{abc}$ \\
\hline & 17.0 & 39.8 & $39.6 \mathrm{aB}$ & $42.1 \mathrm{aA}$ & $37.7 \mathrm{aC}$ \\
\hline & Mean & & 38.2 & 40.1 & 36.5 \\
\hline & $V C(\%)=2.69$ & & & & \\
\hline \multirow{5}{*}{ Mineral $^{1}(\%)$} & 20.0 (control) & 10.0 & $7.5 \mathrm{cB}$ & $14.1 \mathrm{aA}$ & $8.3 \mathrm{cB}$ \\
\hline & 18.5 & 12.0 & $10.8 \mathrm{bA}$ & $12.8 \mathrm{aA}$ & $12.3 \mathrm{bA}$ \\
\hline & 17.0 & 13.7 & $12.7 \mathrm{aA}$ & $14.2 \mathrm{aA}$ & $14.2 \mathrm{aA}$ \\
\hline & Mean & & 10.3 & 13.7 & 11.6 \\
\hline & $\operatorname{VC}(\%)=12.92$ & & & & \\
\hline
\end{tabular}

1 - Significant interaction among factors $(p<0.05)$. For each independent variable, means followed by different capital letters within line or small letter within column are statistical different by Tukey test $(p<0.05)$. 
Furlan RL, Faria Filho DE de, Rosa PS, Macari M

Table 4 - Effect of environmental temperature and diet protein level on chemical composition (\% dry matter) of wings at 42 day-old broilers.

\begin{tabular}{|c|c|c|c|c|c|}
\hline \multirow[t]{2}{*}{ Variables } & \multirow{2}{*}{$\begin{array}{c}\text { Crude } \\
\text { Protein (\%) }\end{array}$} & \multicolumn{3}{|c|}{ Environmental Temperature $\left({ }^{\circ} \mathrm{C}\right)$} & \multirow[b]{2}{*}{ Mean } \\
\hline & & Hot & Cold & Thermo neutral & \\
\hline \multirow{5}{*}{ Dry matter (\%) } & 20.0 (control) & $36.2 c$ & 36.2 & 36.5 & 36.0 \\
\hline & 18.5 & $36.8 \mathrm{~b}$ & 36.8 & 37.0 & 36.6 \\
\hline & 17.0 & $37.4 \mathrm{a}$ & 37.4 & 37.6 & 37.2 \\
\hline & Mean & & $36.8 \mathrm{AB}$ & $37.0 \mathrm{~A}$ & $36.6 \mathrm{~B}$ \\
\hline & $V C(\%)=1.24$ & & & & \\
\hline \multirow{5}{*}{ Crude Protein (\%) } & 20.0 (control) & $45.1 \mathrm{a}$ & 46.2 & 44.9 & 44.3 \\
\hline & 18.5 & $43.9 \mathrm{ab}$ & 45.0 & 42.4 & 44.2 \\
\hline & 17.0 & $42.7 \mathrm{~b}$ & 45.6 & 40.5 & 42.0 \\
\hline & Mean & & $45.6 \mathrm{~A}$ & $42.6 \mathrm{~B}$ & $43.5 \mathrm{~B}$ \\
\hline & $V C(\%)=3.17$ & & & & \\
\hline \multirow{5}{*}{ Ether extract ${ }^{1}(\%)$} & 20.0 (control) & $39.0 \mathrm{bA}$ & $39.3 \mathrm{CA}$ & 39.2 & $39.1 \mathrm{bA}$ \\
\hline & 18.5 & $38.9 \mathrm{bB}$ & $41.0 \mathrm{bA}$ & 39.6 & $38.8 \mathrm{bB}$ \\
\hline & 17.0 & $41.9 \mathrm{aAB}$ & $42.7 \mathrm{aA}$ & 41.7 & $40.4 \mathrm{aB}$ \\
\hline & Mean & & 39.5 & 41.0 & 39.9 \\
\hline & $V C(\%)=2.55$ & & & & \\
\hline \multirow{5}{*}{ Mineral' $^{1}(\%)$} & 20.0 (control) & 15.7 & 14.7 & 15.8 & 16.7 \\
\hline & 18.5 & 16.6 & 16.2 & 16.6 & 16.8 \\
\hline & 17.0 & 15.7 & 14.0 & 16.9 & 16.1 \\
\hline & Mean & & 15.0 & 16.4 & 16.6 \\
\hline & $\operatorname{VC}(\%)=9.87$ & & & & \\
\hline
\end{tabular}

1 - Significant interaction among factors $(\mathrm{p}<0.05)$. For each independent variable, means followed by different capital letters within line or small letter within column are statistical different by Tukey test $(p<0.05)$

carcass characteristics, whole body composition and efficiencies of nutrient utilization. Journal of the Science of Food and Agriculture 2000; 80:547-554.

Alleman F, Leclercq B. Effect of dietary protein and environmental temperature on growth performance and water consumption of male broiler chickens. British Poultry Science 1997; 38:607-610.

Araújo LF. Estudo de diferentes critérios de formulação de rações, com base em perfis de aminoácidos totais e digestíveis para frangos de corte. [Tese]. Jaboticabal (SP): Universidade Estadual Paulista; 2001.

Baker DH, Han Y. Ideal amino acid profile for chicks during the first three weeks posthatching. Poultry Science 1994; 73:1441-1447.

Baker DH, Robbins KR, Buck JS. Modification of the level of histidine and sodium bicarbonate in the Illinois crystalline amino acid diet. Poultry Science 1979; 58:749-750.

Blair R, Jacob JP, Ibrahim S, Wang P. A quantitative assessment of reduced protein diets and supplements to improve nitrogen utilization. Journal of Applied Poultry Research 1999; 8:25-47.

Borges SA, Maiorka A, Silva AVF. Fisiologia do estresse calórico e a utilização de eletrólitos em frangos de corte. Ciência Rural 2003; 33:975-981.

Branton, SL, Reece, FN, Deaton, JW. Use of ammonium chloride and sodium bicarbonate in acute heat exposure of broilers. Poultry Science 1986; 65:1659-1663.
Brake J, Balnave D, Dibner JJ. Optimum dietary arginine:lysine ratio for broiler chickens is altered during heat stress in association with changes in intestinal uptake and dietary sodium chloride. British Poultry Science 1998; 39:639-647.

Bregendahl K, Sell JL, Zimmerman DR. Effect of low-protein diets on growth performance and body composition of broiler chicks. Poultry Science 2002; 81:1156-1167.

Buyse J, Decuypere E, Berghman L, Kuhn ER, Vandesande F. Effect of dietary protein content on episodic growth hormone secretion and on heat production of male broiler chickens. British Poultry Science 1992; 33:1101-1109.

Carew LB, Evarts KG, Alster FA. Growth and plasma thyroid hormone concentrations of chicks fed diets deficient in essential amino acids. Poultry Science 1997; 76:1398-1404.

Carew LB, Alter FA, Foss DC, Scanes CG. Effect of a tryptophan deficiency on thyroid gland, growth hormone and testicular functions in chickens. Journal of Nutrition 1983; 113:1756-1765.

Church DC, Pond WG. Bases científicas para la nutrición y alimentación de los animales domésticos. Zaragoza: Acribia, 1977.

Costa FGP, Rostagno HS, Albino LFT, Gomes PC, Toledo RS, Vargas Junior JG. Níveis dietéticos de proteína bruta para frangos de corte de 1 a 21 e 22 a 42 dias de idade. Revista Brasileira de Zootecnia 2001; 30:1498-1505.

Dean WF, Scott HM. The development of an amino acid reference 


\section{Furlan RL, Faria Filho DE de, Rosa PS, Macari M}

diet for the early growth of chicks. Poultry Science 1965; 44:803808.

Furlan RL, Macari M. Termorregulação. In: Macari M, Furlan RL, Gonzales E, editores. Fisiologia aviária aplicada a frangos de corte. 2 ed. Jaboticabal : Funep-Unesp; 2002. p. 209-230.

Faria Filho DE. Efeito de dietas com baixo teor protéico, formuladas usando o conceito de proteína ideal, para frangos de corte criados em temperaturas fria, termoneutra e quente. [Dissertação]. Jaboticabal (SP): Universidade Estadual Paulista; 2003.

Ferguson NS, Gates RS, Taraba JL, Cantor AH, Pescatore AJ, Ford MJ, Burnham DJ. The effect of dietary protein on growth, ammonia concentration, and litter composition in broilers. Poultry Science 1998; 77:1481-1486.

Geraert PA, Guillaumin S, Leclerca B. Are genetically lean broilers more resistant to hot climate? British Poultry Science 1993; 34:643653.

Hussein AS, Cantor AH, Pescatore AJ. Effect of low protein diets with amino acid supplementation on broiler growth. Journal of Applied Poultry Research 2001; 10:354-362.

Huston RL, Scott HM. Effect of varying the composition of a crystalline amino acid mixture on weight gain and pattern of free amino acids in chick tissue. Federation Proceedings 1968; 27:1204-1209.

Kerr BJ, Kidd MT. Amino acid supplementation of low-protein broiler diets: 1. glutamic acid and indispensable amino acid supplementation. Journal of Applied Poultry Research 1999a; 8:298-309.

Kerr BJ, Kidd MT. Amino acid supplementation of low-protein broiler diets: 2. Formulation on an ideal amino acid basis. Journal of Applied Poultry Research 1999b; 8:310-320.

Klain GJ, Scott HM, Johnson BC. The amino acid requirement of the growing chick fed a crystalline amino acid diet. Poultry Science 1960; 39:39-44.

Koh K, Macleod MG. Circadian variation in heat production and respiratory quotient in growing broilers maintained at different food intakes and ambient temperatures. British Poultry Science 1999a; 40:353-356.

Koh K, Macleod MG. Effects of ambient temperature on heat increment of feeding and energy retention in growing broilers maintained at different food intakes. British Poultry Science 1999b; 40:511-516.

Lesson S, Summers DJ. Commercial poultry nutrition. 2 ed. Guelph, Ontario. Canada: University Books; 1997. 350p.

Longo FA. Estudo do metabolismo energético e do crescimento em frangos de corte. [Dissertação]. Jaboticabal (SP): Universidade Estadual Paulista; 2000.

Macari M, Furlan RL, Gonzales E. Fisiologia aviária aplicada a frangos de corte. Jaboticabal: Funep; 1994.
Macleod MG. Effects of amino acid balance and energy: protein ratio on energy and nitrogen metabolism in male broiler chickens. British Poultry Science 1997; 38:405-411.

Marks HL, Pesti GM. The roles of protein level and diet form in water consumption and abdominal fat pad deposition of broilers. Poultry Science 1984; 63:1617-1625.

Musharaf NA, Latshaw, JD. Heat increment as affected by protein and amino acid nutrition. World's Poultry Science 1999; 55:233240.

Nieto R, Aguilera JF, Fernandez-Figares I, Prieto C. Effect of a low protein diet on the energy metabolism of growing chickens. Archives of Animal Nutrition 1997; 50:105-119.

Pond WG, Church DC, Pond KR. Basic Animal Nutrition and Feeding. 4 ed. New York: John Wiley \& Sons; 1995.

Sabino HFN. Determinação do nível protéico da dieta para frangos de corte em crescimento. [Monografia]. Jaboticabal (SP): Universidade Estadual Paulista; 2001.

Sakomura NK. Influência da temperatura ambiente sobre a exigência nutricional de aves (frangos de corte, matrizes e galinhas de postura). In: Simpósio Internacional Sobre Instalações e Ambiência; 1998; Campinas, São Paulo. Brasil. p. 267-293.

Sasse CE, Baker DH. Modification of the Illinois reference standard amino acid mixture. Poultry Science 1973; 52:1970-1972.

Smith MO, Teeter RG. Potassium balance of the 5 to 8 week old broiler exposed to constant heat or cycling high temperature stress and effects of supplemental potassium chloride on body weight gain and feed efficiency. Poultry Science 1987; 66:487-492.

Sklan D, Plavnic I. Interaction between dietary crude protein and essential amino acid intake on performance in broilers. British Poultry Science 2002; 43:442-449.

Sterling KG, Costa EF, Henry MH, Pesti GM, Bakalli RI. Responses of broiler chickens to cottonseed- and soybean meal-based diets at several protein levels. Poultry Science 2002; 81:217-226.

Temim S, Chagneau AM, Guillaumin S, Michael J, Peresson R, Geraert PA, Tesseraud S. Effects of chronic heat exposure and protein intake on growth performance, nitrogen retention and muscle development in broiler chickens. Reproduction, Nutrition, Development 1999; 39:145-156.

Temim S, Chagneau AM, Guillaumin S, Michael J, Peresson R, Tesseraud S. Does excess dietary protein improve growth performance and carcass characteristics in heat-exposed chickens? Poultry Science 2000a; 79:312-317.

Temim S, Chagneau AM, Peresson R, Tesseraud S. Chronic heat exposure alters protein turnover of three different skeletal muscles in finishing broiler chickens fed 20 or $25 \%$ protein diets. Journal of Nutrition 2000b; 130:813-819.

Teeter RG. Optimizing production of heat stressed broilers. Poultry Digest 1994; 53:10-27. 
Furlan RL, Faria Filho DE de, Rosa PS, Macari M

Wallis IR, Banalve $D$. The influence of environmental temperature, age and sex on the digestibility of amino acids in growing broiler chickens. Poultry Science 1984; 25:401-407.

Waldroup PW. Influence of environmental temperature on protein and amino acid needs of poultry. Federation Proceedings 1982; $41: 2821-2823$

Zarate AJ, Moran ET, Burnham DJ. Exceeding essential amino acid requirements and improving their balance as a means to minimize heat stress in broilers. Journal of Applied of Poultry Research 2003; 12:33-44. 


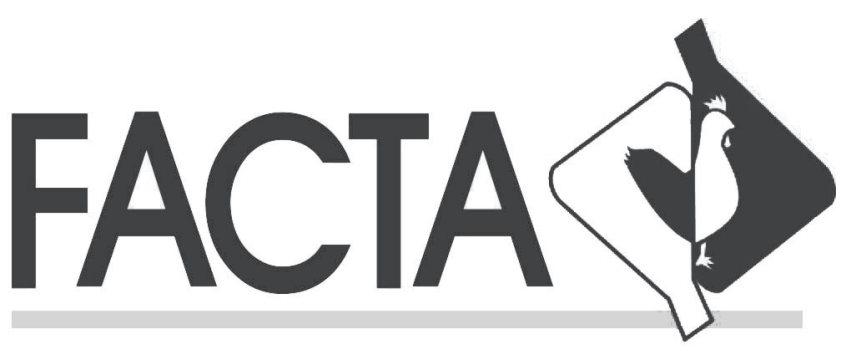

\title{
PUBLICAÇÕES FACTA
}

\author{
Anais da Conferência APINCO'94 \\ Anais da Conferência APINCO'95
}

Anais da Conferência APINCO’97

Anais da Conferência APINCO'98

Anais da Conferência APINCO'99 (2 vol)

Anais da Conferência APINCO'00 (2 vol)

Anais da Conferência APINCO’01 (2 vol)

Anais da Conferência APINCO'02 (1 vol)

Anais da Conferência APINCO'03 (1 vol)

Anais da Conferência APINCO’04 (2 vol + anexo)

Il Simpósio Internacional de Coccidiose Aviária

\section{Col. FACTA - Fisiologia da Reprodução}

Col. FACTA - Manejo de Frangos

II Simpósio da Doença de Gumboro

Simpósio FACTA de Postura Comercial

Doença das Aves

Fisiologia Aviária

Manejo da Incubação

Produção de Frangos de Corte

Para maiores informações:

facta@facta.org.br ou Fone: (19) 3243-6555 